\title{
Gökkuşağı Alabalığı iç organları ve Van Balığı ile hazırlanan balık yemlerinin Gökkuşağı Alabalıklarının büyüme performansı üzerine etkisi
}

\section{Effect of fish feed prepared with trout organs and Van Fish on the growth performance of Rainbow Trout}

\author{
Aslı Çilingir Yeltekin ${ }^{1 *}$ (D) Ahmet F. Yeltekin² \\ 1 Yüzüncü Yıl Üniversitesi Fen Fakültesi Kimya Bölümü, Van, Türkiye \\ 2 T.C. Gıda, Tarım Hayvancılık Bakanlığı Van Gıda Kontrol Laboratuvarı, Van, Türkiye \\ *Corresponding author: aslicyeltekin@gmail.com
}

How to cite this paper:

Çilingir Yeltekin, A. \& Yeltekin, A.F. (2017). Effect of fish feed prepared with trout organs and Van Fish on the growth performance of Rainbow Trout. Ege Journal of Fisheries and Aquatic Sciences, 34(4):409-414. doi: 10.12714/egejfas.2017.34.4.07

\begin{abstract}
Öz: Bu çalışmada ekonomik değeri az olan Gökkuşağı alabalığı (Oncorhynchus mykiss) iç organları ve Van balığının (Alburnus tarichi, Güldenstädt 1814) daha verimli bir şekilde değerlendirilmesi amaçlanmıştır. Balık yetiştiriciliğinde masrafı yüksek olan balık yemi maliyeti düşürülerek, balığa sindirilebilirliği kolay, doğal yeme yakın değerde bir yem verilmiştir. Yarı yaş yem yapım metodu ile daha kolay bir yolla atıklar işlenmiş, ürünün depolama imkânı oluşturulmuştur. Oluşturulan yemlerin kimyasal analizleri yapılarak yemlerin protein, yağ, kül, maya, küf, Mezofilik aerobik bakteri değerleri karşılaştırımıştır. Araştırmadan elde edilen canlı ağırlık artışı ve ekonomik analiz sonuçları; Van balığı ve Alabalık iç organı ile yapılan yarı yaş yemlerin gökkuşağı Alabalıklarının beslenmesinde kullanılabileceğini ve yem giderlerinde bir azalma yapacağını göstermiştir.
\end{abstract}

Anahtar kelimeler: Balık yemi, gökkuşağı Alabalığı, Van Balığı, balık yan ürün

Abstract: In this study, it was aimed to evaluate more efficiently Rainbow trout (Oncorhynchus mykiss) internal organs not consumed by humans and Van fish (Alburnus tarichi, Güldenstädt 1814), which have low economic value. Easy digestible feed for Rainbow trout were prepared that is low cost and similar to natural food. The wastes were processed in an easy way with the semi-wet feed construction method and the product was stored. The chemical analyzes of the prepared feeds were made. Protein, fat, ash, yeast, mold and Mesophilic Aerobic Bacteria values of the feeds were compared. Results of live weight gain and economic analysis obtained from the study; It has been shown that semi-aged feeds made with Van fish and trout internals can be used in feeding Rainbow trout and will reduce feed costs.

Keywords: Fish feed, rainbow trout, Van fish, by-product

\section{Gíriş}

Yeni kaynakların geliştirilmesi ve mevcut kaynakların en iyi şekilde değerlendirilmesi artık her alanda öncelikli konular arasında yer almaktadır. Su ürünleri işleme, sanayi atıklarının değerlendirilmesi ve elde edilen ürünün depolama masraflarının azaltııması önemli ekonomik kazançlar sağladığı gibi çevrenin korunmasına da katkı sağlamaktadır.

Su ürünleri işleme fabrika atıkları büyük bir potansiye oluşturmaktadır. Atıklar çoğunlukla kabuk, iç organlar, deri, kılçık ve küçük miktarda et parçalarından oluşmaktadır (Jaswal, 1989). İşleme fabrikaları artıkları değerlendirilmeden denize döküldüğünde kirliliğe sebep olarak çevre sağlığını olumsuz yönde etkilemektedir. Bu artıkların değerlendirilmesi hem su ürünleri endüstrisi açısından hem de halk sağlığı açısından oldukça önemlidir. Kop ve Korkut 2010, yaptıkları çalışmada alabalıkların beslenmesinde kontrol grubu (normal ticari yem) ile işleme atıklarından elde edilen balık ununu kullanarak oluşturulan yemleri karşılaştırmışlardır. İki yem arasında önemli bir gelişim farkının olmadığı belirtilmiştir. Ton balığının \%4050'si, somon balıklarının \%30-35'i istiridyelerin \%75-80'i, yengeçlerin \%70-75'i, karideslerin \%50-55'i atık maddelerden oluşmaktadır (Hermes, 1998).

Yetiştiricilikte en yüksek gideri yem masrafı oluşturmaktadır. Başta balık unu, balık yağı olmak üzere yem yapımında kullanılan önemli hammaddelerin fiyatları gittikçe artmaktadır. Bu nedenle balık yetiştiriciliğinde kullanılacak değişik yem maddeleri araştırılmaktadır. Bunun yanı sıra düşük maliyetli hazırlanan yemlerin optimum canlı ağırlık artışını sağlaması gerekmektedir (Bharadwaj vd., 2002; Li vd., 2002; Cheng ve Hardy, 2002). Bu amaçla pek çok araştırma yapılmış ve yapılmaya devam etmektedir. 
Bu çalışmada, protein bakımından zengin bir yem olası için Alabalık iç organları ve Van balığının tamamı kullanılarak hazırlanan yarı yaş yemler ile beslenen Alabalıkların gelişme performansı, pelet yemlerle beslenen alabalıklar ile kıyaslanmıştır. Ayrıca kullanılan her üç yemin maliyeti de karşılaştırılmıştır

\section{MATERYAL VE METOT}

\section{Balık}

Çalışma Van'ın Gürpınar ilçesinde bulunan özel bir Alabalık çiftliğinde yapıImıştır. Bu çiftlikte bulunan 10×3×1 m ebatlarında 3 adet beton havuz kullanılmıştır. Tesiste kullanılan kaynak suyunun ortalama su sıcaklığı $12^{\circ} \mathrm{C}$ (en yüksek $16^{\circ} \mathrm{C}$ en düşük $8{ }^{\circ} \mathrm{C}$ ), suda çözünmüş oksijen miktarı $9.5 \mathrm{mg} / \mathrm{L}$ ve suyun ortalama pH'sı 7.4 olarak tespit edilmiştir (Portatif oksijen metre YSI). Van balığı, avlanma mevsiminde yerel marketten temin edilmiştir. Çalışmada kullanılan balıklara herhangi bir zarar verilmediği için etik kurul raporuna T.C. Gıda Tarım ve Hayvancılık Bakanlığı'nca gerek görülmemiştir.

Çalışmada her bir grupta 100 adet balık olacak şekilde toplam 300 adet balık üç gruba ayrımıştır. Balıklar günlük olarak yem alımı kesilinceye kadar (ad-libitum) yemlenmiştir. Yem tüketimi ve yemden yararlanma oranları her bir grup için ayrı ayrı tüketilen yem miktarları üzerinden hesaplanmıştır. Gökkuşağı Alabalıkları porsiyon ağırlığına ulaşıncaya kadar (90 gün) çalışmaya devam edilmiştir. Çalışmanın başında, ortasında (45. gün) ve sonunda (90 gün) üç gruptaki her bir balık elektronik terazide tartılarak, bunların ortalama ağırıkları tespit edilmiştir (Anderson ve Gutreuter, 1989).

Balık beslemede gelişimin izlenmesini sağlayan çeşitli yöntemler bulunmaktadır (Korkut vd. 2007). Çalışma sonunda elde edilen veriler aşağıdaki formüle göre hesaplanmıştır (Riche vd., 2004)

$\mathrm{SBO}=\frac{[\ln \text { Son canlı ağırlık }(\mathrm{g})-\ln \text { İlk canlı ağırlık }(\mathrm{g})]}{\text { Gün sayıSı }} \times 100$

Yem Dönüşüm Oranı $=\frac{\text { Tüketilen toplam yem }}{\text { Toplam canlı ağırlık artışı }}$

\section{Gruplar ve yem hazırlığı}

Bu çalışmada yaklaşık $100 \mathrm{~g}$ ağırlığında olan 300 adet canlı Gökkuşağı alabalığı (Oncorhynchus mykiss), Gökkuşağı alabalığı artıkları, Van balığı (Alburnus tarichi, Güldenstädt 1814), soya unu ve buğday kepeği kullanılmıştır.

Çalışmada; 1.gruba: Alabalık pelet yemi, 2. gruba: $\% 50$ kıyılmış alabalık iç organı + \%30 Soya Fasulyesi Unu (SFU) + \%20 Buğday Kepeği (BK) içeren yem, 3. gruba: \%50 kıyılmış Van balığı + \%30 SFU + \%20 BK içeren yem olmak üzere 3 farklı yem kullanıımışıı (Tablo 1). Yemlerde kullanılan alabalık iç organı, çalışmanın yapılacağı tesisten, Van balığı, avlanma mevsiminde yerel marketten temin edilip dondurularak saklanmıştır. Pelet yem, üretici bir firmadan, soya fasulyesi ve buğday kepeği de piyasadan temin edilmiştir

Serum glikoz ve protein tayininde, Kolorimetrik (Spektrofotometre benzeri) yöntemden yararlanılmıştır (Fujimaki ve Isoda, 1990). Diğer yandan balıklardan heparinsiz olarak doğrudan alınan kan örneklerinden yapılan kan yaymaları, My Grünwald-Giemsa karışık boyama tekniğine uygun olarak boyanmıştır (Kocabatmaz ve Ekingen, 1984; Konuk, 1981). Boyalı yaymalar ışık mikroskobu (Olympus $\mathrm{CH}$ 20 ) ile $\times 100$ 'lük objektifte incelenmiştir. Her bir yayma için 100 lökosit sınıflandırılmış ve lökosit hücre formülleri (lenfosit, monosit, nötrofil, eozinofil) yüzde olarak ifade edilmiştir (Fujimaki ve Isoda, 1990).

Tablo 1. Yem türüne göre oluşturulan gruplar

Table 1. Groups formed according to feed type

\begin{tabular}{|c|c|c|}
\hline Grup 1 & Grup 2 & Grup 3 \\
\hline $\begin{array}{l}\text { Alabalık pelet } \\
\text { yemi }\end{array}$ & $\begin{array}{l}\% 50 \text { kıyılmış alabalık iç } \\
\text { organı }+\% 30 \text { SFU }+\% 20 \\
\text { BK }\end{array}$ & $\begin{array}{l}\% 50 \text { kıyılmış Van } \\
\text { balı̆ı }+\% 30 \text { SFU + } \\
\% 20 \text { BK }\end{array}$ \\
\hline
\end{tabular}

Kıyıımış Alabalık iç organı ve kıyıımış Van balığı ayrı ayrı 65-67 ${ }^{\circ} \mathrm{C}$ 'de 30 dakika çift cidarlı kazanda içme suyu kalitesinde su verilerek pastörize edilmiştir. \%50 kıyılmış Alabalık iç organı + \%30 Soya Fasulyesi Unu (SFU) + \%20 Buğday Kepeği (BK) belirtilen oranlarda karıştırılmıştır. Karışım pelet makinesinden geçirilerek kurutma dolabında \% 9-10 nem içeriği oluşana kadar kurutulmuştur. Aynı işlem Van balığından hazırlanan yem için de tekrar edilmiştir. Elde edilen yemler kuru, ışık görmeyen, havalandırması uygun bir yerde muhafaza edilmiştir (Tablo 2).

Çalışmada kullanılan yemlerin ekonomik analizleri için Kasım 2013 ürün fiyatlarından yararlanılmıştır. Maliyet hesaplamaları tesis, işçilik, yakıt gibi giderler dahil edilmeden; balık alış fiyatı, yem masrafı ve balık satış fiyatı göz önüne alınarak yapıımıştır. Çalışmada kullanılan alabalık pelet yemin $\mathrm{kg}$ fiyatı $3.89 \mathrm{TL}$, soya fasulyesi ununun $\mathrm{kg}$ fiyatı $8.74 \mathrm{TL}$, buğday kepeğinin $\mathrm{kg}$ fiyatı $0.43 \mathrm{TL}$ ve Van balığının kg fiyatı 3.88 TL üzerinden hesaplanmıştır. Alabalık iç organı ücretsiz temin edilmiştir. Elde edilen bu sonuçlar ile 2017 fiyatları kullanılarak hesaplanan ekonomik analiz değerleri kıyaslanmıştır.

Bu fiyatlar üzerinden her bir grup için maliyet aşağıdaki gibi hesaplanmıştır:

Yem Gideri $=($ TTYM) $x($ YM)

Denemede kullanılan alabalık, Van balığı içeren yemler için;

Yem Maliyeti: [(TTYM x $0.5 \times$ iO-VBF $)+($ TTYM $\times 0.3 \times$ SUF $)+($ TTYMx0.2 x BKF] 
Tüketilen Top. Yem Mik. (kg): TTYM, Yem Maliyeti (TL): YM, Soya Ununun kg Fiyatı (TL)): SUF, İç Organ veya Van Balığı kg Fiyatı (TL): IO-VBF, Buğday Kep.kg Fiyatı (TL): BKF şeklinde hesaplanmıştır.

\section{Kimyasal analizler}

Hazirlanan yemlerin protein tayini, Kjendahl metodu kullanılarak yapılmıştır. Yağ tayini için Soxhlet cihazı kullanılmışıır. Kül tayini, hazırlanan yemlerin $550^{\circ} \mathrm{C}$ ' de kül fırınında küllendirilip kalıntının tartımı yapılarak tespit edilmiştir. Mezofilik aerobik bakteri tespiti için TSE'nin TS 7703 EN ISO 4833 nolu kitapçığında yer alan metot kullanılmıştır. Yine maya ve küf gelişimini tespit etmek için TSE'nin TS ISO 21 527-1 kitapçığında yer alan metotlar kullanıımışıı.

\section{BULGULAR VE TARTIŞMALAR}

$\mathrm{Su}$ ürünlerinin işlenmesi, sanayi atıklarının değerlendirilmesi ve ürünün depolama masraflarının azaltılması önemli ekonomik kazançların yanı sıra çevre korumasına da katkı sağlamaktadır. Yapmış olduğumuz bu çalışmada Alabalık yetiştiriciliği için, Alabalık iç organları, atıkları ve Van balığı (Alburnus tarichi, Güldenstädt 1814) kullanılarak yarı yaş yem üretildi, yem maliyetleri belirlendi ve bu yemlerin balık gelişimine katkıları araştıılarak aşağıdaki bulgular elde edildi.

Hazırlanan yemlerin kimyasal analizlerine göre; Van balığı ile yapılan yemin protein ve yağ oranlarının Gökkuşağı Alabalığı (Oncorhynchus mykiss) iç organları ile yapılan yemden daha yüksek olduğu tespit edildi (Tablo 2). Güllü ve Güzel (2003) Van balığında (Alburnus tarichi, Güldenstädt 1814) silajdan pelet yem yapımı üzerine bir çalışma yapmışlardır. Bu çalışmada, balık silajından hazırlanan pelet yemin maliyeti, balık unundan hazırlanan ticari pelet yemlerin maliyetinden daha düşük bulunmuştur. Sunduğumuz çalışmada yağ oranı bu çalışmadaki değerlerden daha yüksek iken protein ve kül oranı daha düşük bulunmuştur (Tablo 2).

Balıkhane artıkları balıkçlık mevsimlerinde ucuza veya ücretsiz olarak temin edilebilmekte ve Alabalıklara verilebilmektedir. Bu tür yemler yetiştiricilik maliyetlerinde oldukça önemli düzeyde indirime yol açmaktadır (Harlıoğlu, 2011). Türkiye'de üretilen su ürünlerinin miktarı türlere göre incelendiğinde öncelikle Alabalık, Hamsi, Sardalya, İstavrit ve Palamut şeklinde sıralanmaktadır (Tuik, 2013). Ayrıca iç organların vücut ağırlığına oranı bakımından Palamut balığı (Sarda sarda) yüzde 6.71 (Erkoyuncu vd., 1994), iken Gökkuşağı Alabalığında (Oncorhynchus mykiss) yüzde 12.24'tür (Ustaoğlu ve Bircan, 1998). Yapılan araştırmalara göre, çiftliklerde yetiştirilen Gökkuşağı Alabalığının 5002 ton kadar iç organının atık haline geldiği söylenebilir (Türker ve
Büyükhatipoğlu, 2006). Gökkuşağı Alabalığına sığır işkembesinin bir bölümünden hazırlanan yemlerle 240 gün süren bir çalışma yapılmıştır. Çalışma sonunda en yüksek canılı ağırık artışı sadece pelet yem verilen grupta, en düşük canlı ağırlık artışı ise $3 / 4$ oranında sığır işkembesi içeren yemle beslenen grupta elde edilmiştir. (Dinçer ve Aras, 1990). Sığır dalağının Gökkuşağı Alabalığında büyüme hızı ve yaşama oranına etkisinin incelendiği 182 günlük bir çalışmada yem dönüşüm oranı ortalama 2.63 olarak tespit edilmiştir (Aras ve Aras,1992). Norveç'te Kalamar (Todarodes sagittarus) (Asgard, 1987) ve Köpek Balığı (Squalus acanthias) iç organlarının (Asgard ve Austreng, 1985) salmon ve Gökkuşağı Alabalığı için bir yem kaynağı olarak çeşitli şekillerde kullanılabileceği, ayrıca Mavi Midye (Mytilus edulis)'nin de Gökkuşağı Alabalı̆ına diğer yem maddeleri ile birlikte verilebileceği bildirilmiş̧ir (Berge ve Austreng, 1989). Gümüş' ün (2011) Gümüş balığı ununun yavru sazan (Cyprinus carpio) yemlerinde kullanım potansiyelinin belirlenmesi amacıyla yaptığı bir çalışmada beş farklı yem kullanılarak akvaryumdaki balıklar 13 hafta süreyle beslenmiştir. Elde edilen sonuçlara göre Gümüş balığı unu içeren yemlerle beslenen balıkların büyüme performansının hazır satılan yem ile beslenen balıklardan daha düşük olduğu bulunmuştur.

Tablo 2. Kullanılan yemlerin kimyasal analiz sonuçları Table 2. Chemical analysis results of feeds used

\begin{tabular}{lll}
\hline $\begin{array}{l}\text { Yapılan kimyasal } \\
\text { analizler }\end{array}$ & $\begin{array}{l}\text { Alabalık iç } \\
\text { organları ile } \\
\text { yapılan yem }\end{array}$ & $\begin{array}{l}\text { Van balığı ile } \\
\text { yapılan yem }\end{array}$ \\
\hline $\begin{array}{l}\text { Kuru Maddede } \\
\text { Protein \% }\end{array}$ & 25.73 & 27.12 \\
Kül \% & 2.64 & 2.1 \\
Yağ \% & 18.61 & 22.06 \\
Mezofilik aerobik & $3.1 \times 10^{6}$ & $1.1 \times 10^{6}$ \\
bakteri (Kob/g) & $5.4 \times 10^{3}$ & $5.5 \times 10^{3}$ \\
Maya(Kob/g) & $1.3 \times 10^{3}$ & $1.3 \times 10^{3}$ \\
Küf & & \\
\hline
\end{tabular}

Tablo 3 de görüldüğü üzere Alabalık iç organları ile yapılan yemin kg maliyeti $2.71 \mathrm{TL}$ ile en düşük olmuştur. Bunun nedeni en önemli girdi olan Alabalık iç organlarının bedelsiz olarak elde edilmesidir. Projenin tasarımı aşamasında ortalama fiyatı 1.5 TL olan Van balı̆̆ı çalışma döneminde 3.88 TL (2017 yılı 4.00 TL) (KDV Dahil) fiyata temin edilmiştir. Van balığı arzında fiyat istikrarı olmayışı yem maliyetine olumsuz yansımışır. Pelet yem fiyatı ise 4TL yem baz alınarak piyasa araştırması neticesinde kg'ı ortalama 3.89 TL (2017 yilı 4.50 TL) olarak tespit edilmiştir. 
Tablo 3. Denemede kullanılan yemlerin birim maliyetleri

Table 3. Unit costs of feeds used in the trial

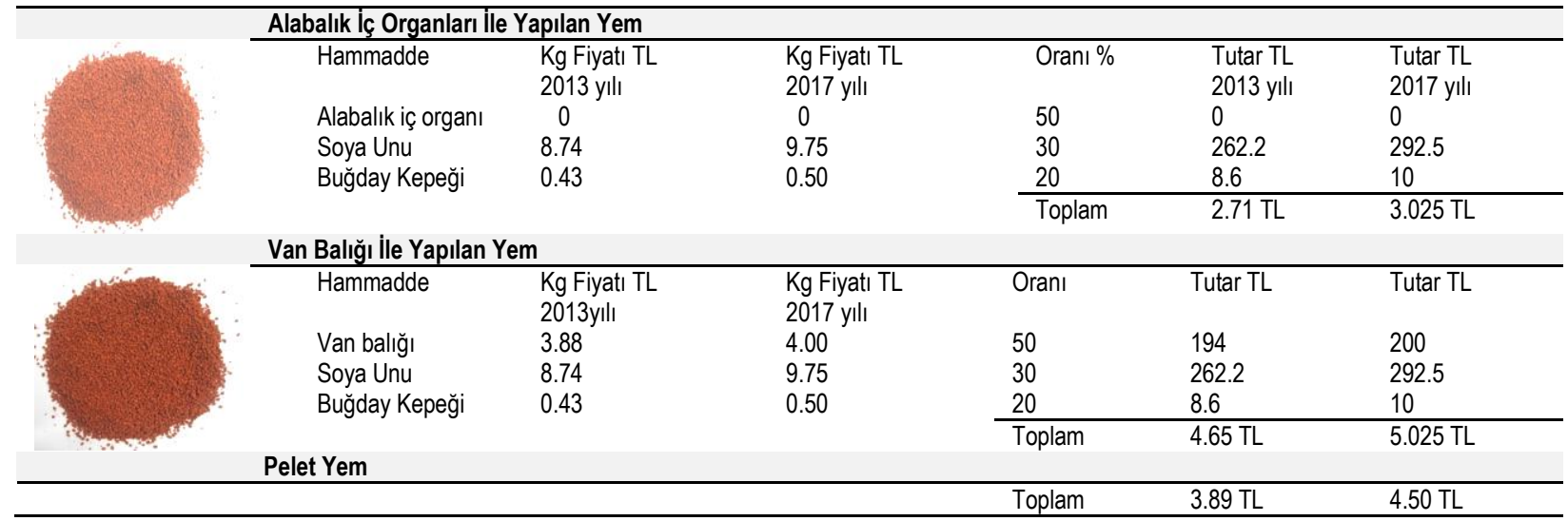

Deneme sonunda bireysel canlı ağırlık artışı ve günlük canlı ağılık artışı bakımından en yüksek değer alabalık pelet yem verilen grubundan elde edilmiştir. Alabalık atıkları ile hazırlanan yemi yiyen grup, pelet yem ve Van balığı ile hazırlanan yem tüketen guruplardan daha düşük derecede ağırlık artışı sağlamıştır. Van balığından hazırlanan yem ile beslenen gurubun ağırlık artışı, Alabalık atıklarından hazırlanan yem ile beslenen gruba göre daha fazla, pelet yem ile beslenen guruba göre daha düşük değerdedir (Tablo 4).

Romero vd., (2014) Mercan balığına deniz yengeci ve denizkestanesinden yem hazırlamışlardır. 180 gün süren çalışma sonucunda denizkestanesi ile beslenen grubun daha iyi gelişim gösterdiğini tespit etmişlerdir. Gökkuşağı Alabalığı beslenmesinde midye etinin kullanımı üzerine yapılan bir denemede yem dönüşüm oranları hazır yemde 1.83 ve midye ile hazırlanan yemde 1.1 olarak saptanmıştır (Aral vd., 1999) Yapılan bu çalışmalar ile sunduğumuz çalışmanın örtüştüğü görülmektedir. Hernández ve Roman (2016) Gökkuşağı Alabalıklarına soya fasulyesi ve bakladan yem hazırlamışlardır. 66 gün süren çalışmada, normal yem ve baklalı yem ile beslenen grupların ağırlık artışının yaklaşık olduğu fakat soya fasulyeli yem ile beslenen grubun biraz daha fazla ağırlık artışı gösterdiği tespit edilmiştir. Bizim çalışmamızda ve diğer çalışmalarda bitkisel protein kaynağı olarak soya unu kullanımı ile ilgili genetiği değiştirilmiş bu gıda ürününün etkilerinin uzun dönemde ayrıntılı biçimde incelenmesi ve ona göre kullanılması Gıda Güvenliği açısından faydalı olabilir.

Ekonomik analiz sonuçlarında, tüketim miktarı fazla olan alabalık atıkları ile hazırlanan yarı yaş yemin fiyatı pelet yemden yaklaşık olarak \%30 daha uygundur. Bu durum önemli bir maliyet kazanımı olarak göze çarpmaktadır (Tablo 5). Van balığının Van ilinde balık hali kurulması ile fiyat istikrarı yakalayacağı düşünülmektedir. Uzun süreçli düşünülür ise Van balığı sürekli bir protein kaynağı olarak önem arz etmektedir

Tablo 4. Gelişme analizi sonucunda elde edilen veriler

Table 4. Results of developmental analysis

\begin{tabular}{llll}
\hline & Pelet Yem Grubu & Alabalık Atıkları Grubu & Van balığı Grubu \\
\hline Denemede Kullanılan Balık Sayısı (Adet) & 100 & 100 & 100 \\
Deneme Sonu Balık Sayısı (Adet) & 94 & 92 & 91 \\
Ölüm Oranı \% & 6 & 8 & 9 \\
Deney Başı Ortalama Ağırık (g) & 99.92 & 99.78 & 100.01 \\
Deney Sonu Ortalama Ağılık (g) & 310.24 & 251.49 & 257.16 \\
Günlük Ağırlık Artış Oranı (g) & 2.5 & 1.7 & 1.9 \\
Toplam Tüketilen Yem Miktarı (g) & 26826 & 35410 & 33264 \\
Yem Dönüşüm Oranı & 1.45 & 2.95 & 2.87 \\
Spesifik Büyüme Oranı & 1.25 & 1.02 & 1.04 \\
\hline
\end{tabular}


Tablo 5. Ekonomik analiz sonucu elde edilen veriler

Table 5. Economic analysis result data

\begin{tabular}{|c|c|c|c|c|c|c|}
\hline & $\begin{array}{l}\text { Alabalık } \\
\text { atıkları grubu } \\
2013 \\
\end{array}$ & $\begin{array}{l}\text { Alabalık } \\
\text { atıkları grubu } \\
2017 \\
\end{array}$ & $\begin{array}{l}\text { Van balığı grubu } \\
2013\end{array}$ & $\begin{array}{l}\text { Van balığı } \\
\text { grubu } 2017\end{array}$ & $\begin{array}{l}\text { Pelet yem } \\
\text { grubu } 2013\end{array}$ & $\begin{array}{l}\text { Pelet yem } \\
\text { grubu } \\
2017 \\
\end{array}$ \\
\hline Tüketilen Toplam Yem(kg) & 35.41 & 35.41 & 33.264 & 33.26 & 26.826 & 26.83 \\
\hline Birim Maliyet Fiyatı (TL) & $2.71 \mathrm{TL}$ & $3.025 \mathrm{TL}$ & $4.65 \mathrm{TL}$ & $5.025 \mathrm{TL}$ & $3.89 \mathrm{TL}$ & $4.50 \mathrm{TL}$ \\
\hline Toplam Maliyet (TL) & $95.96 \mathrm{TL}$ & 107.12 TL & $154.68 \mathrm{TL}$ & 167.13 TL & 104.35 TL & $120.74 \mathrm{TL}$ \\
\hline Pelet Göre Fiyat Oranı (\%) & $+\% 30 \mathrm{Kar}$ & $+\% 11.28$ & $-\% 24$ & $-\% 38.42$ & - & - \\
\hline $\begin{array}{l}\text { Toplam Tüketimde Pelet Yeme Göre } \\
\text { Fark }\end{array}$ & $+8.39 \mathrm{TL}$ & $+8.39 \mathrm{TL}$ & $-50.32 \mathrm{TL}$ & $-50.32 \mathrm{TL}$ & $0.00 \mathrm{TL}$ & $0.00 \mathrm{TL}$ \\
\hline
\end{tabular}

Bu çalışmada; hazırlanan yemlerin Gökkuşağı Alabalığının büyüme ve gelişmesine etkisi ile yetiştiricilikte oldukça önemli paya sahip olan yem giderlerinin azaltılmasına katkısı araştırımıştır. Elde edilen sonuçlara göre hazırladığımız yemlerin verildiği gruplarda, pelet yem verilen gruplardan daha az ağılık artışı gözlenmiştir. Bu gruplar arasındaki ağırlık artışı farkı; hazırladığımız yemlerin protein oranının pelet yemlerdeki protein oranından daha düşük olmasına, yüksek protein içeren balık ununun kullanılmamasına ve vitamin-minera yetersizliğine bağlanabilir. Yem dönüşüm oranı, Alabalık iç organları ve Van balığı ile hazırlanan yemlerde pelet yeme göre daha yüksek değerde gözlenirken spesifik büyüme oranı, her

\section{KAYNAKÇA}

Anderson, R.O. \& Gutreuter S.J. (1989). Fisheries Tecniques. Third Printer. Maryland, USA. 283.

Aral, O., Ağırağaç, C. \& Yiğit, M. (1999). Karadeniz'de ağ kafeslerde alabalıkların (Oncorhynchus mykiss) beslenmesinde midye etinin kullanımı üzerine bir araşııma. Türk Veterinerlik ve Hayvancılık Dergisi, 23(1):23-29

Aras, N.M. \& Aras, M.S. (1992). Farklı periyotlarda verilen sığır dalağının damızlık alabalıklarda (S. gairdneri) canlı ağırlık artış hızı ve yaşama gücüne etkisi üzerinde araştırmalar. Akdeniz Üniversitesi Isparta Mühendislik Fakültesi 7. Mühendislik Haftası Tebliğ Özetleri, 25 -27 Mayıs, Isparta.

Asgard, T. (1987). Squid as feed for salmonids. Aquaculture, 61:259-273. doi: 10.1016/0044-8486(87)90154-2

Asgard, T. \& Austreng, E. (1985). Dogfish offal, ensiled or frozen, as feed for salmonids, Aquaculture, 49:289-305. doi: 10.1016/0044-8486(85)90086-9

Berge, G.M. \& Austreng, E. (1989). Blue mussel in feed for rainbow trout. Aquaculture, 81:79-90. doi: 10.1016/0044-8486(89)90232-9

Bharadwaj, A.S., Brignon, W.R., Gould, N.L., Brown, P.B. \& Wu, Y.V. (2002) Evaluation of meat and bone meal in practical diets fed to juvenile hybrid striped bass Morone chrysops x M. Saxatilis. Journal of the Aquaculture Society, 33(4):448-457. doi: 10.1111/j.1749-7345.2002.tb00024.x

Cheng, Z.J. \& Hardy, R.W. (2002). Apparent digestibility coefficients of nutrients and nutritional value of poultry by-product meals for rainbow trout (Oncorhynchus mykiss) measured in vivo using settlement. Journal of the Aquaculture Society, 33(4):458-465. doi: 10.1111/j.1749-7345.2002.tb00025.x

Dinçer, R. \& Aras, S. (1990). Alabalık rasyonlarında çeşitli düzeylerde kullanılan sığır şirdeni'nin "Abomasus" ve günlük yemleme sayısının gökkuşağı alabalığının (Salmo gairdneri) büyüme hızı, yemden yararlanma ve yaşama gücüne etkileri. Doğa Türk Zooloji Dergisi, 14(2):237-251. üç yem grubu için yakın değerler vermiştir. Elde edilen veriler ışığında yarı yaş yem yapımı, değerlendirilmesi ve bu yemle alabalıkların beslemesi konusuna farklı bir bakış açısı getirilmeye çalışımıştır. Sonuç olarak, balıkların büyüme performansı ve yem maliyeti bakımından hazırladığımız yemlerin uygun olduğu düşünülebilir.

\section{TEŞEKKÜR}

T.C. Gıda Tarım ve Hayvancılık Bakanlığını tarafından TAGEM/HSGYAD/12/A05/P01/ nolu proje olarak desteklenmiştir. Tüm destekleri için teşekkür ederiz. .

Erkoyuncu, İ., Erdem, M., Samsun, O., Özdamar, E. \& Kaya, Y. (1994). Karadeniz'de avlanan bazı balık türlerinin et verimi, kimyasal yapısı ve uzunluk-ağırlık ilişkisinin belirlenmesi üzerine bir araştırma. İstanbul Üniversitesi Su Ürünleri Dergisi, 1-2:181-191.

Fujimaki, Y. \& Isoda, M. (1990). Fine-structural study of leucocytes in the goldfish, Carassius auratus. Journal of Fish Biology, 36(6):821-831. doi: 10.1111/j.1095-8649.1990.tb05630.x

Güllü, K. \& Güzel, Ş. (2003). İnci kefalı (Chalcalburnus tarichi) silajının pelet yem yapımında kullanımı üzerine bir araştırma. Ekoloji, 12(48):19-23.

Gümüş, E. (2011). Effect of Replacement of Fishmeal with Sand Smelt (Atherina boyeri) Meal on Growth, Feed Utilization and Body Compositionof Mirror Carp Fry (Cyprinus carpio). Kafkas Universitesi Veteriner Fakültesi Dergisi, 17(3):363-369.

Harlıoğlu, A.G. (2011). Balık Artıklarının Balık Yemlerinde Kullanılan Yağların Elde Edilmesinde Kullanımı. Eğirdir Su Ürünleri Fakültesi Dergisi, 7(2):5663.

Hernández, A.J. \& Roman, D. (2016). Phosphorus and nitrogen utilization efciency in rainbow trout (Oncorhynchus mykiss) fed diets with lupin (Lupinus albus) or soybean (Glycine max) meals as partial replacements to fsh meal. Czech Journaj Animal Science, 61(2):67-74. doi: 10.17221/8729-CJAS

Hermes, E. (1998). Fish Processing Technology in the Topics. Waste Management Chapter 17. Quezon city, Philippines, 272-279.

Jaswal, A.S. (1989). Methodology Investigations for the Production of Amino acid Hydrolysate From Shrimp Waste. Canadian Institute of Food Technology Journal, 22(5):460-463. doi: 10.1016/S0315-5463(89)70597-6

Kocabatmaz, M. \& Ekingen, G. (1984). Değişik tür balıklarda kan örneği alınması ve hematolojik metotların standardizasyonu. Doğa Bilim Dergisi, D1, 8, 2, s 149-159

Konuk, T. (1981). Pratik Fizyoloji, Second Ed. A.Ü. Vet. Fak. Yayınları, Ankara, Turkey. 
Korkut, A.Y., Kop, A., Demirtaş, N. \& Cihaner, A. (2007). Balık Beslemede Gelişim Performansının İzlenme Yöntemleri. Ege Journal of Fisheries and Aquatic Sciences, 24(1-2):201-205.

Kop, A. \& Korkut, A.Y. (2010). "Effects of Diets with Different Fish Meal Origins on the Performance of Rainbow Trout Oncorhynchus mykiss (Walbaum)". Medwell Journals. Journal of Animal and Veterinary Advances, 9(3):581583. doi: $10.3923 /$ javaa.2010.581.583

Li, M.H., Manning, B.B. \& Robinson, E.H. (2002). Comparison of various animal protein sources for growth, feed efficiency and body composition of juvenile channel catfish Ictalurus punctatus. Journal of the Aquaculture Society, 33(4):489-493. doi: 10.1111/j.1749-7345.2002.tb00028.x

Riche, M., Oetker, M., Haley, D.I., Smith, T. \& Garling D.L. (2004). Effect of feeding frequency on consumption, growth, and efficiency in juvenile tilapia (Oerochromis niloticus). Israeli Journal Aquacult.-Bamidgeh, $56(4): 247-255$.
Romero, J., Ginés, R., Izquierdo, M.S., Haroun, R., Badilla, R. \& Robaina, L. (2014). Effect of dietary substitution of fish meal for marine crab and echinoderm meals on growth performance, ammonia excretion, skin colour, and flesh quality and oxidation of red porgy (Pagrus pagrus). Aquaculture, 422-423.

Türkiye İstatistik Kurumu. 2013. Su Ürünleri İstatistikleri 2013. Internet Internet http://www.tuik.gov.tr. Yayın No: 4349 ISSN 1013-6177. Yücetepe Mah. Necatibey Cad. No: 11406100 Çankaya-Ankara / Türkiye

Türker, A. \& Büyükhatipoğlu, Ş. (2006). Gökkuşağı Alabalıklarının Yemlenmesinde Alabalık Ve Palamut İç Organları veya Hamsi Kullanılmasının Performans ve Yem Maliyeti Üzerine Etkisi. Ondokuz Mayıs Üniversitesi Ziraat Fakültesi Dergisi, 21(2):167-172.

Ustaoğlu, S. \& Bircan, R. (1998). Karadeniz'deki ağ kafeslerde yetiştirilen gökkuşağı alabalığı (Oncorhynchus mykiss)'nın gelişme ve yem değerlendirmesine farklı yemleme düzeylerinin etkileri. Türk Veterinerlik ve Hayvancllik Dergisi, 22(3):285-291. 